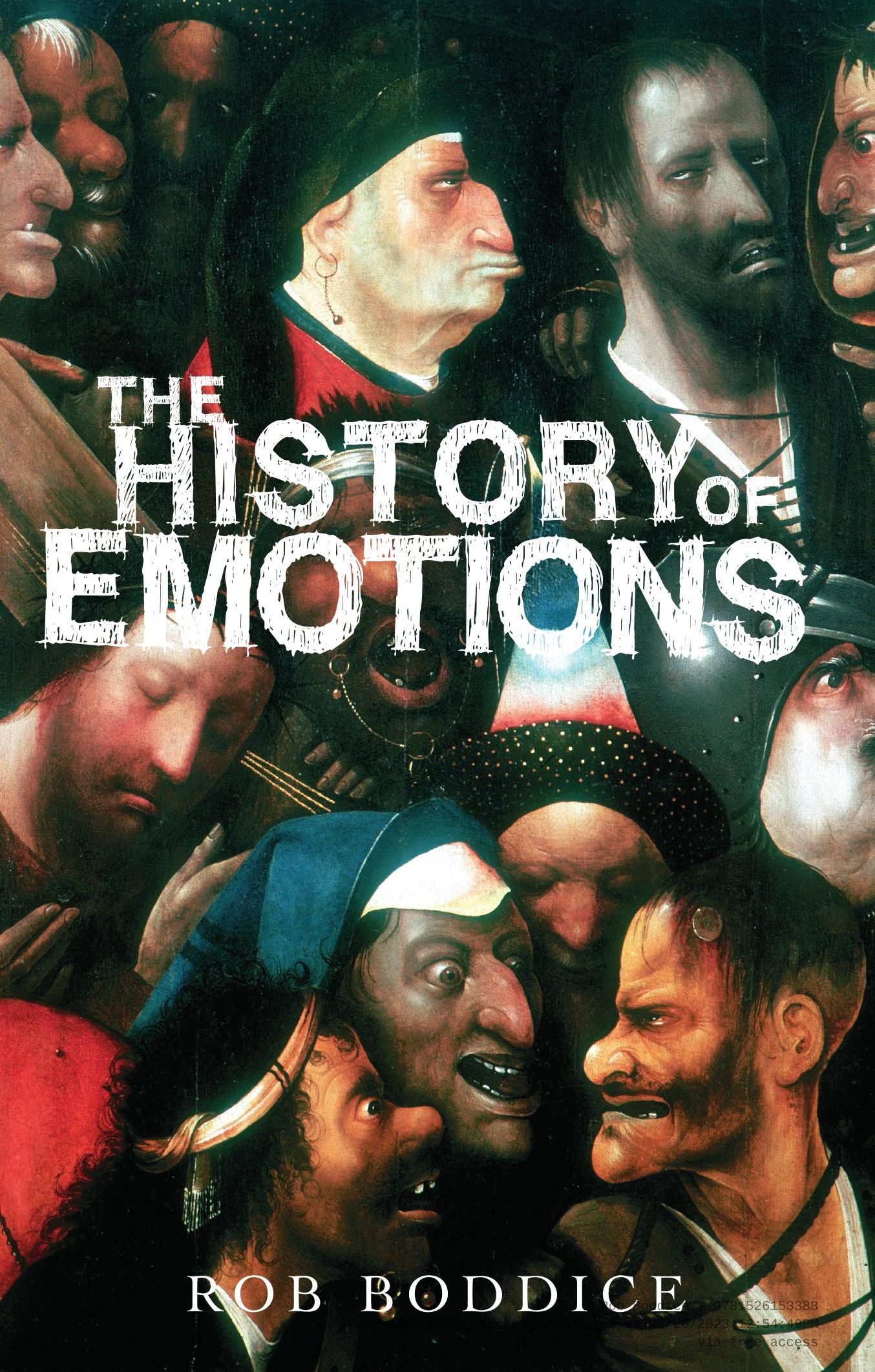




\section{THE HISTORY OF EMOTIONS}

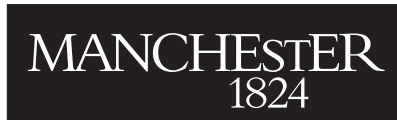

Manchester University Press 
HISTORICAL APPROACHES *

Series editor

Geoffrey Cubitt

The Historical Approaches series aims to make a distinctive contribution to current debate about the nature of the historical discipline, its theory and practice, and its evolving relationships to other cultural and intellectual fields. The intention of the series is to bridge the gap that sometimes exists between learned monographs on the one hand and beginners' manuals on the other, by offering works that have the clarity of argument and liveliness of style to appeal to a general and student readership, while also prompting thought and debate among practising historians and thinkers about the discipline. Titles in the series will cover a wide variety of fields, and explore them from a range of different angles, but will have in common the aspiration of raising awareness of the issues that are posed by historical studies in today's world, and of the significance of debates about history for a broader understanding of contemporary culture.

Also available:

Geoffrey Cubitt History and memory

Joanna de Groot Empire and history writing in Britain c.1750-2012

Matthew Kempshall Rhetoric and the writing of history, 400-1500 


\title{
THE HISTORY OF EMOTIONS
}

\author{
W
}

\author{
Rob Boddice
}

Manchester University Press 
Copyright () Rob Boddice 2018

The right of Rob Boddice to be identified as the author of this work has been asserted by him in accordance with the Copyright, Designs and Patents Act 1988.

\author{
Published by Manchester University Press \\ Altrincham Street, Manchester M1 7JA \\ www.manchesteruniversitypress.co.uk \\ British Library Cataloguing-in-Publication Data \\ A catalogue record for this book is available from the British Library
}

ISBN 9781784994280 hardback

ISBN 9781784994297 paperback

First published 2018

The publisher has no responsibility for the persistence or accuracy of URLs for any external or third-party internet websites referred to in this book, and does not guarantee that any content on such websites is, or will remain, accurate or appropriate.

Typeset by

Servis Filmsetting Ltd, Stockport, Cheshire 